International Business Management 13 (8): 345-352, 2019

ISSN: $1993-5250$

(C) Medwell Journals, 2019

\title{
The Role of Government Policies to Encourage Small and Medium Enterprises (SMEs) in Kuwait
}

\author{
Abrar Fahad Abduallah Almai \\ Faculty of Economics and Political Science, University of Cairo, Giza, Egypt
}

\begin{abstract}
This study aimed to highlight the importance of SMEs in Kuwaiti economy, identify the most important governmental procedures which have been taken by the State of Kuwait with the purpose of encouraging investors to establish their enterprises, increase its participation and contributions to improve macroeconomic indicators and increase economic growth. The study plan to use descriptive analytical approach to study SMEs in State of Kuwait, highlight procedures and policies which have been taken by Kuwaiti government to encourage SMEs and increase their share in national economy. This study concludes that procedures and policies which related to the development of SMEs by State of Kuwait have a positive impact in developing these enterprises and that lead to enhance its developmental role and participation in improvement of macroeconomic indicators like increasing non-oil exports and gross added value for SMEs which lead to increase non-oil GDP (Gross Domestic Product) in Kuwait during the study period from 2002 till 2015. This study is important for researchers, institutions, universities, research centers, organizations and governments which interested in knowing and examine SMEs role. As it highlights the importance of SMEs in Kuwait and governmental procedures which have been taken by Kuwaiti government to encourage these enterprises.
\end{abstract}

Key words: Kuwait, SMEs, doing business environment, economy, enterprises, analytical

\section{INTRODUCTION}

We cannot ignore and neglect the role of SMEs in national economy. In the last few years policy makers focus their attention on SMEs, especially in the developing countries because of the increasing of disappointments with the outcomes of development strategy which focus on large industries, huge capital and huge industrial imports. The importance of SMEs lies in exploiting local resources, generating jobs, developing rural and remote areas, mobilizing local savings, increasing investment and providing self-employment and opportunities for skilled workers (Taiwo et al., 2012).

There was a considerable difference between specialists concerning the unified definition of SMEs because of the existence of some considerations affecting the development of a comprehensive and unified definition of SMEs. One of the most important among these considerations is the degree of economic growth among countries, the level of technological development, the difference of economic sector in which enterprises work, the number of criteria used to differentiate between enterprises. The most important criteria used are the number of workers, the size of assets, capital and sales volume (CSES, 2012).

The enterprise is considered small if it contains between 10-49 employees or workers and it considered medium if it contains between 50-250 employees and workers, in addition micro-enterprise contains $<10$ employees (Infelise and Valiante, 2013). The World Bank defines these SMEs as they contain $<300$ workers and sales number is $<15$ and $<5$ million dollars in assets.

Despite the difficulty of formulating a unified concept for SMEs, everyone stressed out the importance of these enterprises as most developing countries are concentrating their efforts on them, thus, encouraging the establishment of small and medium industries, especially after ensuring their ability and efficiency in addressing the main problems facing different economies which is to a greater extent the huge industries. The growing attention to SMEs both formal and national, in addition to its large labor capacity is due to formulating a field to develop administrative, technical, productive and marketing skills. Moreover, it opens a wide field in front of individual initiatives and self-employment. Thus, it reduces the pressure on the public sector to offer job opportunities. SMEs have also proved flexibility and ability to deal with all economic situations mainly in recession period. These enterprises were the least affected by the consequences of the recent financial crisis in 2008, despite the repercussions of this crisis on banks and SMEs financing institutions where the financing gap for these enterprises increased (OECD, 2008).

Importance of SMEs globally: Small and Medium-sized Enterprises (SMEs) play an important role in economic development in worldwide. The SMEs are the backbone of the private sector, (SMEs) share up to $90 \%$ of the 
private sector worldwide and between $50-60 \%$ of jobs worldwide (Hobohm, 2001). For example, in China SMEs are lead the Chinese economy, contributing more than $60 \%$ of GDP and $50 \%$ of tax revenue, employing more than $75 \%$ of the labor force and $68 \%$ of China's merchandise exports come from these projects, according to 2014 statistics. The number of SMEs in China in 2015 reached 20 million as the small and medium-sized companies own $65 \%$ of patents, $75 \%$ of technological innovations and more than $80 \%$ of new products in China. (Sham and Pang, 2014).

In Germany, small and medium-sized companies are the backbone of the economy, according to 2016 statistics there are approximately 3.46 million German enterprises classified as SMEs which form up to $99.5 \%$ of the total number of companies. These companies also achieved annual sales of approximately 273 billion $€$ in 2016 which is $35.3 \%$ of the total sales of German companies. These companies employed 17.18 million employees which is $58.3 \%$ of the total employment subject to social security contributions. While exports of small and medium-sized companies in Germany were around 208.2 billion euros in 2016 , representing approximately $17 \%$ of the total export value, small and medium-sized companies played an important indirect role in German exports as suppliers to large export companies. Small and medium-sized companies shares amounted about $53.5 \%$ of Germany's total net value added in the same year. These companies spent 9.4 billion $€$ on research and development which represent $11.9 \%$ of total German R\&D expenditure in 2016 (Simon, 2009).

In Kuwait, the number of SMEs in 2015 reached 38,759 enterprises, contributed to the employment of 186,000 workers and contributed with a value added of one billion and 305 million KWD (4 billion and 294 million \$) for the same year (central statistical bureau, 2015). Due to the decline in oil prices globally, the major economies began to extract oil and increase the supply of oil in the market and many of the major countries began to provide resources for alternative energy other than oil which means the beginning of the decline of the golden age of the oil era and oil revenues on which Kuwait relied in the past decades. Therefore, it was imperative for economic policy makers in the State of Kuwait to plan well for the post-oil era and diversify the resources and sources of national income (Vohra, 2017). As a result, the Kuwaiti government considers that SMEs are the real chance of the Kuwaiti economy through which it can sustain growth, boost income sources, tackle unemployment and counter the decline in world oil prices.

\section{MATERIALS AND METHODS}

The role of government policies to encourage SMEs in Kuwait: Governments take various procedures and issues new laws to contribute in development processes. The government policy has the greatest impact to encouraging and attracting investment in general and SMEs in particular. For example, in the latest tax reform in Japan issued in March, 2019, a special section is devoted in tax reform law to support and provide incentives to SMEs which granted small enterprises a tax deduction or tax exemption of 8 million yen. Over the next 10 years, SMEs that meet certain conditions their taxes will be overlooked (KPMG, 2018). In the United States, President Donald Trump approved the new tax reform in December 2017 which reduced taxes from $35-21 \%$ and gave special incentives to SMEs including that the law stipulated that small companies could use the basis of cash accounting and are excluded from certain special accounting rules that are applied on large and medium-sized companies, other than the tax incentive package approved by the new business environment act (IRS.USA).

Therefore, the government's efforts in the field of small and medium enterprises attract the attention of major countries globally. Therefore, the State of Kuwait has exerted great efforts in supporting and encouraging small and medium enterprises and provided them with support and assistance in order to raise the proportion of its projects in line with the objectives contained in the development plan. The most prominent forms of government support in Kuwait for this type of enterprise are to provide financing to small and medium enterprises in various ways such as financial grants to enterprises or loans with zero interest or low interest as well as tax exemption, in addition to other forms of support such as financial, administrative and marketing consulting services. The following are the most important measures and steps taken by the government of Kuwait to support and develop small and medium enterprises.

Industrial bank of Kuwait: portfolio of craft activities and small enterprises: The portfolio of craft and small enterprises was established with a capital of 50 million KWD to finance Kuwaiti crafts and small enterprises (Anonymous, 1998). The SME portfolio has set limits and criteria for the financing of this type of project. Accordingly, the portfolio finances SMEs which has cost does not exceed 500,000 KWD (1.638 million \$). The portfolio provides financing to entrepreneurs which may reach $400,000 \mathrm{KWD}(1.310$ million \$) with a maximum of $80 \%$ of the project capital. The beneficiaries are granted a grace period determined by the portfolio based on the format of the project and starting from the contracting date up to a maximum of 3 years for new projects. The portfolio also provides interest-free loans to existing small enterprises at $25,000 \mathrm{KWD}(82,000 \$)$ to meet operating expenses. As a prerequisite for enjoying the financing provided by the portfolio an integrated feasibility study should be available covering all aspects 
of the project (economic, technical, marketing ...) and this study proves that the expected return is not $<15 \%$ of the invested capital (Industrial Bank of Kuwait).

Manpower restructuring program: Manpower and Government Restructuring Program (MGRP) of the State of Kuwait was established in 1997 with the aim of correcting the imbalances of the domestic labor market and changing the employment paths of citizens from the government sector to the private sector. The restructuring program supports and encourages national manpower to work in non-governmental organizations through various media campaigns and radio and television programs to change perceptions of working in the private sector. The program disburses financial benefits to workers in the private sector including social allowances, children's allowance, a cost of living allowance, a job search allowance and any other financial increases that a civil servant gets. The program also supervises the preparation of specialized training courses to qualify job seekers in line with the needs of the labor market and encourage them to start their small and medium-sized enterprises. The program also contributes to the cost of training courses aimed at developing the capabilities and the potentials of their managers who are working in the private sector companies. Executive order (767/1997).

Small-sized enterprises administration: A small projects department has been established which follows the government to provide free consultancy services in the field of feasibility studies and provide up-to-date data and information on labor markets. The department of small projects seeks to spread the concept of small projects in the community and guide the appropriate national manpower to prepare them to enter the sector of small projects depending on scientific bases and provide technical support services in order to help them with co-operation of the relevant authorities to start and continue running such successful projects with positive returns, reduce unemployment, develops the national economy and diversify of the national income sources (Executive order 767/1997).

Accordingly, the entrepreneur and the project owner will enjoy features and services provided by the administration in order to facilitate the creation and viability of small enterprises. The most prominent services provided can be summarized as follows: providing training programs for entrepreneurs who prefer self-employment.

Providing prepared ideas for small enterprises that are well-considered or that have been applied in local, gulf or regional market. Participating with governmental and non-governmental parties in supporting small enterprises. Finding promotional marketing outlets for entrepreneurs to offer their products and services in cooperative societies and local exhibitions.
Free workshops and training programs for small projects owners or entrepreneurs. Feasibility study and assessment by the consulting staff (advisory staff for providing administrative, legal, marketing and technological consultations).

On revising the statistics of project management, it turned out there was a steady increase in the total number of people registered for the small enterprises administration. Moreover, statistics indicate that the total number of people registered for the administration, during the period between 2010-2015 has increased from 34-832, respectively (Anonymous, 2015). In addition, the annual rates of growth in the total number of the registered for the small enterprises management program have increased. In turn, this reflects the program success in playing its role in supporting small enterprises sector through the significant development of the number of the registered during the mentioned years. Similarly, this has increased the positive effect of the small enterprises administration on the development of thinking and orientation of youth, constituting the target group and on the increase of social awareness about the importance of these projects as one of the significant sources of self-development and income growth.

The national fund for small and medium enterprise: The national fund for small and medium enterprise development was established with a capital of 2 billion KWD ( 6 billions $\$$ ). To explain, this act with its several articles aim at supporting youth, combating unemployment and enabling the private sector to achieve economic growth in Kuwait. This is by means of building an organization with a world-class performance to enhance entrepreneurship ability to provide national economic prosperity (Anonymous, 2013).

Moreover, the fund has defined main goals such as the contribution to creating productive employment opportunities for the Kuwait is in private sector, increasing the participation of small and medium enterprises in the local economy, in addition to creating an appropriate environment for small and medium enterprises activities. These goals help to achieve the fund's vision which revolves around building a pioneering society that encourages creativity and achieves economic development opportunities.

From this perspective and due to the attention to small and medium enterprises, the fund has made a definition for those projects which it supports in the first article of the act as follows: small enterprise: the enterprise in which the number of Kuwaiti workers doesn't exceed four people and its capital is no more than KWD 250,000 (820,000\$). Medium enterprise: the enterprise in which the number of Kuwaiti workers ranges from 5-50 people and its capital is no more than KWD 500,000 (1.638 million dollars). 
Furthermore, the national fund offers enterprises incubator services. That is, it allocated a special department, under the organizational structure of the fund, to take charge of establishing and adopting world-class enterprises incubators. Moreover, this department allocates a part of the fund budget for these incubators to do their activities and the incubators provide a group of services in a number of phases (Anonymous, 2013).

First phase: Training support by cooperating with the support institutions and the specialist organizations in the fields of fund activities in order to provide training and developmental programs for entrepreneurs.

Research support by preparing the researches and studies that help entrepreneurs to turn their ideas into viable enterprises.

Second phase: Technical and advisory support through the provision and delivery of technical consultations for the entrepreneur during their incubation period with its two types.

Internal incubation: The logistic support is being provided by offering a place to host the project for a certain period of time determined by the fund and the incubator according to the development and growth of the enterprise. In this period, all the facilities needed by the project are provided until it moves to the external incubation.

External incubation: The entrepreneur establishes their own enterprise outside the hosting place of the incubator with the benefit of all kinds of financial, technical and advisory support provided by the fund including the provision of land.

Third phase: Connecting those projects with some of the existing projects, thus helping the development of these enterprises and its services for the national economy. Holding symposia, exhibitions and conferences that aim for the growth and development of the enterprises. The fund runs the enterprise on behalf of its owner in case a temporary obstacle preclude him from managing the project a properly.

The fund terms concentrate on the enterprises that are more able to achieve the value-added, the national economy development, the diversity of income sources and the provision of employment opportunities for Kuwaitis. Moreover, the fund concentrates on building an internal environment in a way that is encouraging for entrepreneurship and creative for entrepreneurs and employers and that can be a fundamental basis for achieving more economic opportunities that are productive for the Kuwaiti youth.
Accordingly, the number of beneficiaries of the services and training programs provided by the national fund, since, the beginning of their provision until January, 2017 is 984 beneficiaries. Moreover, there are 141 projects, benefiting from the funding program, since, its foundation on March, 2016 until January, 2017 (national fund for SMES, statistics 2017).

Tax exemption: Taxes can affect the growth through discouraging the investment and reducing the incentives of investors by the means of the high taxes and the low depreciation on companies. Taxes can also undermine the employment growth by affecting its earnings and abilities to develop itself or by reducing the available choices of working or acquiring other skills from education due to the increase in tax burden on personal income. Tax policy can also discourage productivity growth because it leads to reducing the expenditure on scientific research and development due to the increase in tax burden (Engen and Skinner, 1996).

Therefore, the Kuwaiti legislator was careful to exempt companies and small and medium enterprises from taxes. That is Act No. 3 of 1955 and Act No. 2 of 2008 regulated taxes in Kuwait and the act provided for exempting local companies operating in Kuwait from income tax. Accordingly, this tax exemption for the local companies operating in Kuwait is a significant contribution by the Kuwaiti Government machinery to supporting the local private sector in general and small and medium enterprises in particular. Low taxes or tax exemption constitute the most significant ways and means for encouraging small and medium enterprises and investment in general in order to stimulate economic development.

Boskin and Gale (1987) study, it was indicated that tax reduction leads to increasing direct investments, thus, directly affecting capital accumulation. Moreover, Venti and Wise (2000) study clarified that the contributions of personal retirement allowances have significantly increased due to tax reduction which contributes to increasing capital accumulation as well. There is no doubt that tax reduction and tax exemptions effectively contribute to encouraging and attracting investment, in addition to increasing small and medium enterprises. This is what Kuwaiti government was careful to achieve through exempting small and medium enterprises from income tax.

General overview of the governmental policy effect on small and medium enterprises in Kuwait: The procedures adopted by Kuwaiti government contributed to increasing the number of small and medium enterprises and facilitating their activities. That has already been reflected in improving Kuwait ranking in doing business report which measures the ease of conducting business. 
Int. Business Manage., 13 (8): 345-352, 2019

Table 1: The development of the number of companies, benefiting from SMEs administration in Kuwait during the period between 2010 and 2015

\begin{tabular}{lcccccc}
\hline Years & 2010 & 2011 & 2012 & 2013 & 2014 & 2015 \\
\hline Number of companies registered in SMES administration & 34 & 54 & 238 & 729 & 621 & 832 \\
\hline
\end{tabular}

Small enterprises administration statistics between 2010-2015

Table 2: The development of Kuwaiti government rank in doing business report

\begin{tabular}{|c|c|c|}
\hline Years & Indicators & Action \\
\hline \multirow[t]{2}{*}{2008} & Obtaining credit & $\begin{array}{l}\text { Private Credit Bureau in Kuwait extended its coverage by adding retailers to those who provide credit } \\
\text { information }\end{array}$ \\
\hline & Getting building permits & $\begin{array}{l}\text { Kuwait has reduced the time needed to deal with building permits by inserting an automatic system to } \\
\text { issue the technical approvals of facilities services }\end{array}$ \\
\hline \multirow[t]{2}{*}{2010} & Resolving the insolvency & $\begin{array}{l}\text { Kuwait has enhanced the insolvency by inserting a new legal action that allows financially troubled } \\
\text { companies that are about to suffer from insolvency to restructure }\end{array}$ \\
\hline & Cross-border trade & $\begin{array}{l}\text { Kuwait has reduced the time needed for customs clearance by improving administrative procedures and } \\
\text { employees training }\end{array}$ \\
\hline 2014 & $\begin{array}{l}\text { Protecting minority } \\
\text { investors }\end{array}$ & $\begin{array}{l}\text { Kuwait has strengthened investors protection by enabling the minority contributors from asking to employ } \\
\text { an auditor to revise company activities }\end{array}$ \\
\hline 2016 & Starting business & Kuwait made it easier to start a business by reducing the minimum capital requirements \\
\hline 2017 & Cross-border trade & $\begin{array}{l}\text { Kuwait facilitated export and import operations by inserting electronic customs linkages and electronic } \\
\text { exchange for information between the various agencies }\end{array}$ \\
\hline \multirow[t]{2}{*}{2018} & Property registration & $\begin{array}{l}\text { Kuwait facilitated property registration by reducing the number of days needed for property registration, } \\
\text { in addition to improving the transparency of land management system }\end{array}$ \\
\hline & Starting business & $\begin{array}{l}\text { Kuwait made it easier to start a business by establishing one-step shop system, in addition to improving } \\
\text { Online Registration System (ORS) }\end{array}$ \\
\hline \multirow[t]{2}{*}{2019} & $\begin{array}{l}\text { Protecting minority } \\
\text { investors }\end{array}$ & $\begin{array}{l}\text { Kuwait enhanced the protection of minority investors by calling for an independent review on transactions } \\
\text { with related parties, in addition to clarifying ownership and oversight structures }\end{array}$ \\
\hline & Starting a business & Kuwait made it easier to start a business by abolishing the minimum capital requirements \\
\hline
\end{tabular}
Doing business report different years

Moreover, the number of small and medium enterprises and their staff has increased. Non-oil exports have also increased thanks to the increase in the number of small and medium enterprises which is represented in the following points.

The role of small enterprises administration: On revising the statistics of small enterprises administration, it has been made clear that there is a steady increase in the total number of the registered at the small enterprises administration. The data in Table 1 indicates that the total number of people registered at the administration during the period between 2010 and 2015 has increased from 34-832 in year 2015 .

Moreover, the annual rates of growth in the total number of people registered for the small enterprises administration program have increased. In turn, this reflects the program success in playing its role in supporting small enterprises sector through the significant development of the number of the registered during the mentioned years. Similarly, this has increased the positive effect of the small enterprises administration on the development of thinking and orientation of youth, constituting the target group and on the increase of social awareness about the importance of these projects as one of the significant sources of self-development and income growth.

The improvement of doing business report indicators: Doing business report tackles ten indicators for monitoring the ease of doing business which are: starting a business, getting building permits having access to

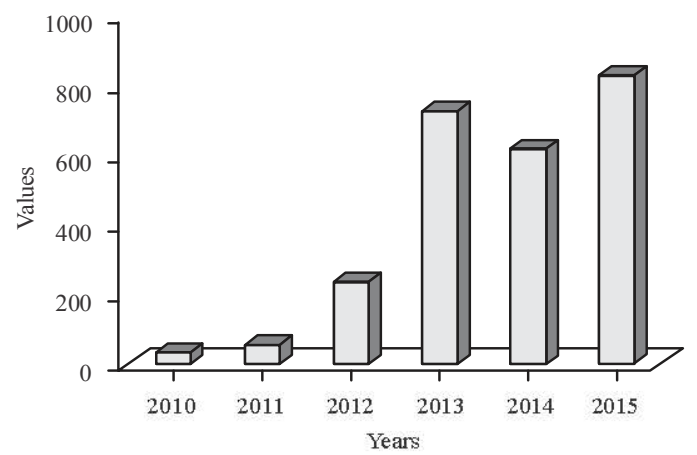

Fig. 1: The development of the number of companies, benefiting from SMEs administration in Kuwait during the period between 2010 and 2015; Small enterprises administration statistics between 2010-2015

electricity, registering property, obtaining credit, protecting investors, paying taxes, cross-border trading, enforcing contracts and resolving the insolvency (Fig. 1).

Since, 2008, Kuwait took a series of actions that had a great positive effect on facilitating business environment, particularly in small and medium enterprises. The largest proportion of these actions was concentrated in the field of starting a business, in addition to some actions related to getting building permit and cross-border trade, etc (Table 2).

Figure 2 shows Kuwait development in the composite indicator of doing business from 2015-2019 and this is the available data of Kuwait in doing business database in the 
Int. Business Manage., 13 (8): 345-352, 2019

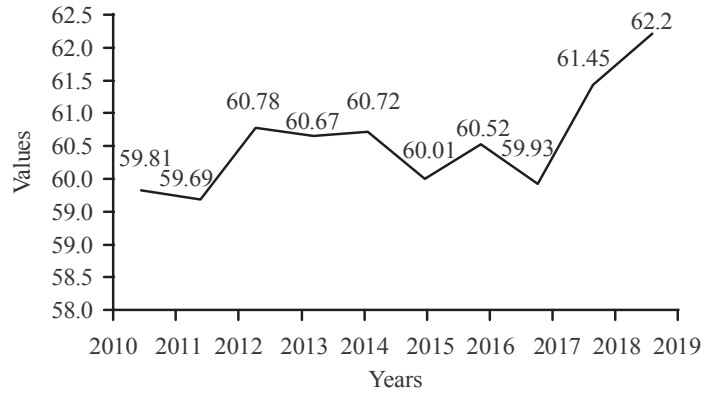

Fig. 2: The development indicator of doing business in Kuwait; Doing business report. different years

World Bank. That is the figure indicates that despite the volatility of performance, the composite indicator lies between two ranges which are 59.5-62.5. It could be said that there is an upward trend in 2018 and 2019 (they cover 2017 and 2018 consecutively). Table 2 clarifies the details of the governmental actions that contributed to improve business environment in Kuwait from 2008-2019 according to the reports of these years.

\section{RESULTS AND DISCUSSION}

The evolution of SME indicators: By reviewing the data of the central administration of statistics in the State of Kuwait from 2002-2015 we found that:

C1-the size of SMEs: SMEs constitute $94 \%$ of the total number of establishments operating in the Kuwaiti economy during the period from 2002-2015 which is a high contribution rate while the large enterprises amounted to $5.9 \%$ which indicates the growing share of SMEs in the Kuwaiti economy during the period; they are also the nucleus for starting large projects in the future (Fig. 3).

C2-development of non-oil exports: As shown in Table 3, total non-oil exports in the State of Kuwait increased from 393 million KWD in 2002 to 1.6 billion KWD in 2015 with an average annual growth rate of $12.5 \%$. This indicates the growing role of the non-oil sector, including SMEs and the success of government policies that have contributed to increasing the number of SMEs. Thus, the increase in its production activity contributes to increasing domestic non-oil exports (Fig. 4).

C3-evolution of the total value added of SMEs: Table 4 shows that the total value added of SMEs in Kuwait has increased from 820 million KWD in 2002 to 1.305 billion KWD in 2015 with an average annual growth rate of $4 \%$. It indicates the growing role of SMEs in participating in increasing non-oil GDP mentioned above which emphasizes the importance of these

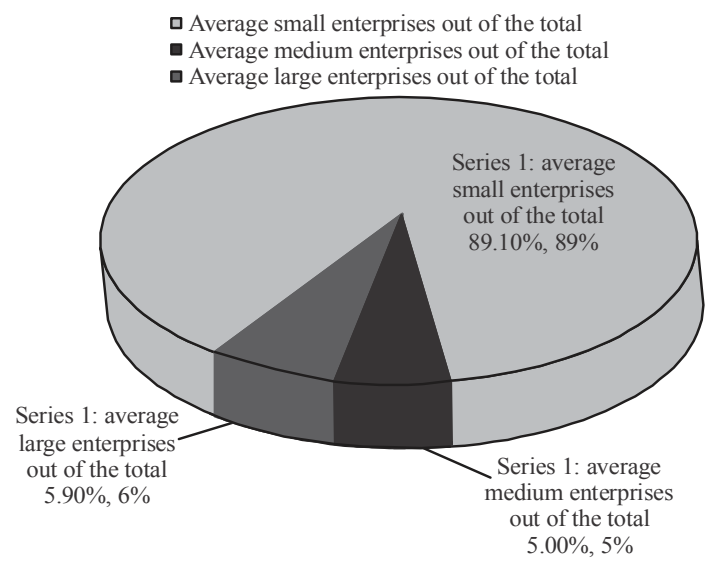

Fig. 3: The average number of projects (large, medium and small) in the State of Kuwait during the period from 2002-2015; Prepared by the researcher based on the data of the-central statistical bureau, annual survey of establishments-multiple years

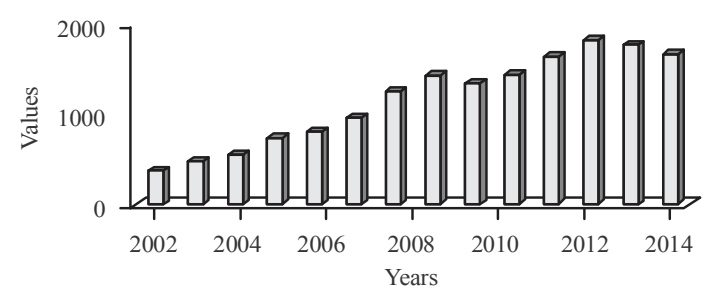

Fig. 4: Total non-oil exports during the period from 2002-2015; Prepared by the researcher based on data Table 3

Table 3: Total non-oil exports during 2002-2015

\begin{tabular}{lc}
\hline Years & $\begin{array}{c}\text { Total petroleum non-exports in } \\
\text { Kuwait (millions of Kuwait Dinar) }\end{array}$ \\
\hline 2002 & 393 \\
2003 & 498 \\
2004 & 567 \\
2005 & 758 \\
2006 & 823 \\
2007 & 990 \\
2008 & 1281 \\
2009 & 1456 \\
2010 & 1370 \\
2011 & 1472 \\
2012 & 1674 \\
2013 & 1858 \\
2014 & 1803 \\
2015 & 1699 \\
\hline
\end{tabular}

Central statistical bureau, annual statistical group, multiple years

projects to participate in improving the performance of the national economy and the success of government policies that contributed to increase the number of SMEs and improve their economic performance (Fig. 5 and Table 4).

C4-non-petroleum GDP: Table 5 shows that the non-oil GDP in Kuwait in which SMEs contribute, increased from 7.6 billion KWD in 2002 to 24.7 billion KWD in 2015 
Int. Business Manage., 13 (8): 345-352, 2019

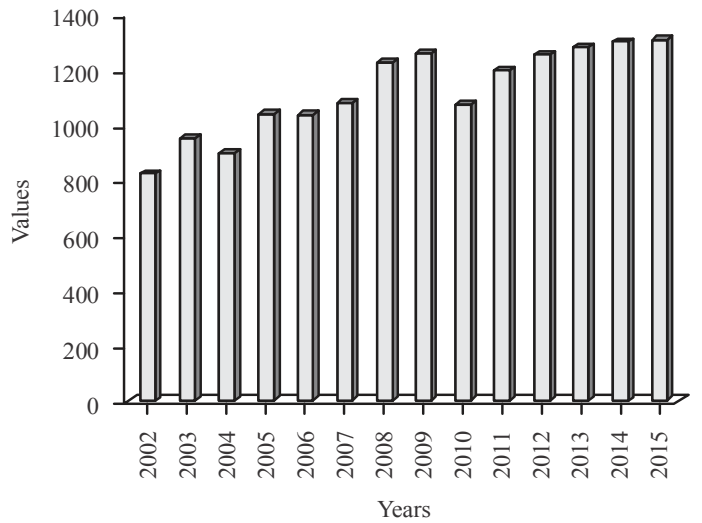

Fig. 5: Total value added of SMEs during 2002-2015; Prepared by the researcher based on data Table 4

Table 4: Total value added of SMEs during 2002-2015

\begin{tabular}{lc}
\hline Years & $\begin{array}{c}\text { Value added for SMES } \\
\text { (millions of Kuwait Dinar) }\end{array}$ \\
\hline 2002 & 820.7 \\
2003 & 948.6 \\
2004 & 895.7 \\
2005 & 1039.6 \\
2006 & 1033.9 \\
2007 & 1079.0 \\
2008 & 1222.2 \\
2009 & 1257.0 \\
2010 & 1069.6 \\
2011 & 1194.1 \\
2012 & 1251.1 \\
2013 & 1280.4 \\
2014 & 1296.5 \\
2015 & 1305.4 \\
\hline Central statistical bureau, annual survey of establishments, multiple \\
years
\end{tabular}

Table 5: Non petroleum GDP in Kuwait

\begin{tabular}{lc}
\hline Years & $\begin{array}{c}\text { Non petroleum GDP in Kuwait } \\
\text { (millions of Kuwait Dinar) }\end{array}$ \\
\hline 2002 & 7628 \\
2003 & 8930 \\
2004 & 10234 \\
2005 & 12206 \\
2006 & 14105 \\
2007 & 16967 \\
2008 & 17631 \\
2009 & 16962 \\
2010 & 17438 \\
2011 & 20625 \\
2012 & 22697 \\
2013 & 23735 \\
2014 & 24223 \\
2015 & 24730 \\
\hline
\end{tabular}

Central administration of statistics-annual statistical group-for several years

with an average annual growth rate of $9.7 \%$. Which indicates the growing role of the non-oil sector in general and SMEs in particular and the success of government policies that contributed to increasing the number of

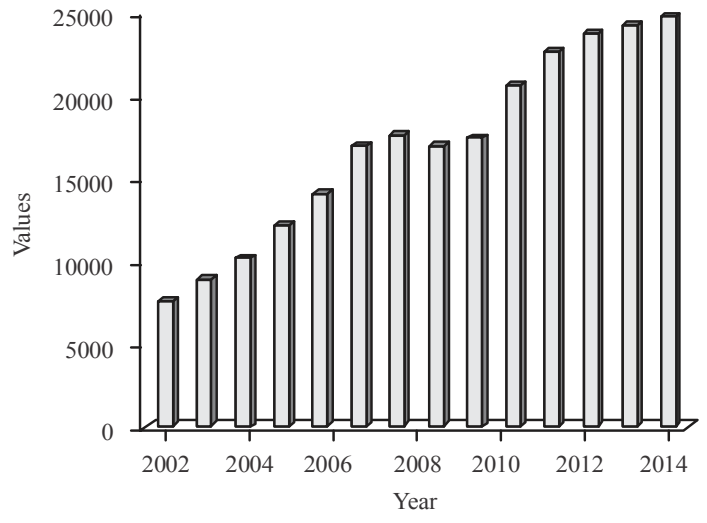

Fig. 6: Non petroleum GDP in Kuwait; Table 5

SMEs which contributed to the increase of non-oil GDP to reduce dependence on oil as a primary generator of GDP in the Kuwaiti economy (Fig. 6).

\section{CONCLUSION}

The study found that SMEs play an important role in the global economic development the study found that SMEs play an important role in the global economic development they contribute to relieving pressure on the public sector to create jobs. These projects represent $90 \%$ of private sector companies and institutions and represent between 50 and $60 \%$ of jobs worldwide. That's why governments around the world have paid increasing attention to SMEs and have worked to remove obstacles that hinder SMEs.

The government of Kuwait has also taken many measures and adopted new policies that will increase the contribution of SMEs to the macro economy and thus increase economic growth. As part of this, the Government of Kuwait established the Industrial Bank of Kuwait (KIB) which in turn contains a portfolio of financing activities for small businesses and small enterprises to provide financial support through financing SMEs that are economically feasible, in addition to the establishment of a program of restructuring the national workforce which works to provide courses aimed at developing the capacities of workers in the private sector and owners of SMEs. The Kuwaiti government has also established the SMEs department which provides technical support to develop, guide and qualify young people to enter the small business sector through the provision of training programs and successful ideas applied in the local, gulf or regional market and marketing of products and services for small enterprises and other services. The government of Kuwait has also established the national fund for the welfare and development of SMEs which will provide technical support and financial support to SMEs to increase the participation of SMEs in achieving economic growth. 
The measures taken by the Kuwaiti government have contributed to increase the number of SMEs and facilitating them which has already shown improvement in the ranking of Kuwait in the doing business report which measures the ease of doing business, Kuwait was ranked 104th in 2014 to become 86th in 2015 out of 190 countries, the number of SMEs increased by $94 \%$ of the average establishments operating in the State of Kuwait during the period from 2002-2015, thus, increasing their employment, the increase in non-oil exports due to the increasing number of these projects with an average annual growth rate of $12.5 \%$ during the same period which indicates the increasing role of the non-oil sector including SMEs. The total added value of SMEs in Kuwait has increased as a result of the positive measures taken by the State of Kuwait as the added value of these projects increased from 820 million KWD in 2002 to 1.305 billion KWD in 2015 which indicates the growing role of SMEs in participating in increasing nonoil GDP this confirms the importance of these projects to participate in improving the performance of the national economy and the success of government policies that contributed to increasing the numbers of SMEs and improve their economic performance and the non-oil GDP in Kuwait to which SMEs contribute, increased from 7.6 billion KWD in 2002 to 24.7 billion KWD in 2015 which indicates the seriousness of the state in reducing dependence on the oil sector and developing the non-oil sector and giving it weight and importance in achieving economic growth in all its components, including SMEs this clears through the increase in the percentage of their participation in the generation of GDP, especially non-oil.

\section{REFERENCES}

Anonymous, 2013. Law98/2013: In 2013, 98 people live in the country. The National Fund for Small and Medium Enterprise Development, Kuwait. https:// translate.google. $\mathrm{com} /$ translate $? \mathrm{hl}=\mathrm{en} \& \mathrm{sl}=\mathrm{ar} \& \mathrm{u}=\mathrm{htt}$ p://www.kbc.gov.kw/Files/Decisionsandlaws/5879ed 78-3c43-4649-b0c0-83970aa3a827.pdf\&prev =search Anonymous, 2015. Services of manpower authority (national manpower). Public Authority of Manpower Shamiya, Kuwait. https://translate.google.com/ translate?hl=en\&sl=ar\&u=https://www.mgrp. org.k $\mathrm{w} /$ \&prev $=$ search

Anonymous, 1998. Law 10/1998: In establishing a financial portfolio with the industrial Bank of Kuwait to support financing. Industrial Bank of Kuwait, Kuwait.
Boskin, M.J. and W.G. Gale, 1987. New results on the effects of tax policy on the international location of investment. Working Paper No. 1862, National Bureau of Economic Research, Cambridge, Massachusetts. https://www.nber.org/papers/w1862. pdf

CSES., 2012. Evaluation of the SMES definition. Center for Strategy and Evaluation Services, Sevenoaks, England, UK. https://publications. europa.eu/en/publication-detail/-/publication/ 5849c2fe-dcd9-410e-af37-1d375088e886

Engen, E. and J. Skinner, 1996. Taxation and economic growth. Natl. Taxt. J., 49: 617-642.

Hobohm, S., 2001. Small and medium-sized enterprises in economic development: The UNIDO experience. J. Econ. Cooperation, 22: $1-42$.

Infelise, F. and D. Valiante, 2013. Why a more accurate EU definition of SMEs matters. No. 8599, Centre for European Policy Studies, Brussels, Belgium. https://ideas.repec.org/p/eps/ ecmiwp/8599.html

$\mathrm{KPMG}$, 2018. Members report and financial statements 2018. KPMG, Amstelveen, Netherlands. https://assets.kpmg/content/dam/kpmg/uk/pdf/2018 /12/annual-review-2018-financial-report.pdf

OECD, 2008. Organization for Economic Co-operation and Development. OECD, Paris.

Sham, T. and I. Pang, 2014. China's SMEs development. OCBC Wing Hang Bank, Hong Kong. https://www. ocbcwhhk.com/webpages_cms/files/Inv estment $\% 2$ 0Newsletter/English/Investment\%20Newsletter_Se p_e(1).pdf

Simon, H., 2009. Hidden Champions of the Twenty-First Century: The Success Strategies of Unknown World Market Leaders. Springer, London, UK., ISBN-13: 978-0387981468, Pages: 402.

Taiwo, M.A., A.M. Ayodeji and B.A. Yusuf, 2012. Impact of small and medium enterprises on economic growth and development. Am. J. Bus. Manage., Vol. 1 , No. 1 .

Venti, S.F. and D.A. Wise, 2000. Choice, chance, and wealth dispersion at retirement. NBER Working Paper No. 7521, National Bureau of Economic Research, Cambridge, Massachusetts. https://www.nber.org/papers/w7521

Vohra, R., 2017. The impact of oil prices on GCC economies. Intl. J. Bus. Soc. Sci., Vol. 8, No. 2. 